\title{
Impact of Access to Credit on the Sustainability of Small and Medium Sized Enterprises in Cameroon
}

\author{
Joachem Meh Bin ${ }^{1 *}$, Sylvanus Ngoata Diangha ${ }^{2}$, Moses Abit Ofeh ${ }^{1}$ \\ ${ }^{1}$ Faculty of Economics and Management, University of Bamenda, Bamenda, Cameroon \\ ${ }^{2}$ Faculty of Economics and Management, University of Yaoundé II, Yaounde, Cameroon \\ Email: *binjoachem@yahoo.com
}

How to cite this paper: Bin, J. M., Diangha, S. N., \& Ofeh, M. A. (2021). Impact of Access to Credit on the Sustainability of Small and Medium Sized Enterprises in Cameroon. American Journal of Industrial and Business Management, 11, 705-718.

https://doi.org/10.4236/ajibm.2021.116046

Received: May 20, 2021

Accepted: June 27, 2021

Published: June 30, 2021

Copyright $\odot 2021$ by author(s) and Scientific Research Publishing Inc. This work is licensed under the Creative Commons Attribution International License (CC BY 4.0).

http://creativecommons.org/licenses/by/4.0/

\begin{abstract}
This paper aims at evaluating the major determinants of access to credit and their impact on the sustainability of SMEs in Cameroon using the 2016 World Bank enterprise survey. The probit model and linear regression model were used and the results show that collateral security, experience, interest rates, corruption and size of loan are the major determinants of access to credit and access to credit has a positive impact on the sustainability of SMEs in Cameroon. From the results, we can recommend the government to formulate an entrepreneurship strategy that will enable the SMEs to have financial access.
\end{abstract}

\section{Keywords}

Access to Credit, Sustainability of Enterprises, Probit Model, Linear Regression Model, Cameroon and SMEs

\section{Introduction}

The outstanding employment capacity and income generating ability as well as the contribution of SMEs in developing economies in particular, make it evident that SME constitutes the backbone for the economic development and sustainability of most if not all the developing economies. As stated by Mullei (2003) they serve as seedbeds for entrepreneurship, create new jobs and provide innovation and technological development. The SMEs tend to introduce business methods, products, and services that help restructure weak agricultural sectors or other uncompetitive transition economies, thereby absorbing labor force that would otherwise drop into the ranks of the poor Mwabili (2014), they generate 
more new jobs than large firms as they tend to introduce relevant innovative ideas, products and business methods (Nguyen et al., 2004).

In a more general manner, SMEs contribute to over $55 \%$ of gross domestic product (GDP) and over $65 \%$ of total employment in high-income countries, over $60 \%$ of GDP and over $70 \%$ of total employment in low-income countries, and over $95 \%$ of total employment and about $70 \%$ of GDP in middle-income countries (OECD, 2004). According to Ofoegbu, Akanbi and Joseph (2013) laying interest on SMEs would contribute to creation of jobs, reduction in income disparity, production of goods and services in the economy, as well as providing a fertile ground for skill development and acquisition, serve as a mechanism for backward integration and a vehicle for technological innovation and development especially in modifying and perfecting emerging technological breakthroughs. SMEs contribute to improved living standards, bring about substantial local capital formation and achieve high level of productivity and capability (Olowe F.T. et al., 2013). Given these vitalities of SMEs, policies gauged at ensuring sustainability of SMEs in both developing and developed economies are of utmost importance.

Cameroon has over 93,969 enterprises of which $99.2 \%$ are SMEs, accounting for $62 \%$ of the country's dominant employment and $31 \%$ of turnover (NIS, 2009), the need for sustainability of SMEs is indispensable for the realization of the government target vision 2035 of rendering the country an emerging economy. Unfortunately, the sustainability of SMEs in Cameroon is challenged by a common phenomenon called access to credit.

There are several elements that hinder the growth of SMEs in Cameroon such as corruption, long administrative procedures, insufficient or lack of infrastructures like roads, electricity, poor legal system and very high transaction costs and custom duties at the ports of shipment (Piabuo et al., 2015). These challenges force the SMEs to resort to inappropriate methods of production or out-dated technology (NIS, 2009). From an enterprise survey (World Bank/IFC, 2008), this phenomenon is observable in the entire sub-Saharan region, where $51 \%$ of small enterprises and $45 \%$ of medium enterprises consider access to finance as their major obstacle.

The government of Cameroon in 2004 created the ministry of small and medium-sized enterprises, Social Economy and Handicraft in December 2004, and the most recent creation of a bank for financing SMEs (Piabuo et al., 2015), access to credit for SMEs is still extremely limited and some of the SMEs die out even before growth. A little is actually understood why a good number of these SMEs are less sustainable. Taking a look at the Cameroon financial system we observe a very low level of backing operation as it contains only seventeen Main Banks and it seems much like the condition to access credit in these, few banks are only suitable for large firms.

In this perspective, we seek in this paper to identify the major determinants of SMEs' access to credit in a holistic stand point of Cameroon and evaluate the impact of access to credit on the sustainability of SMEs. This will enable us to 
put in place policy recommendations that could help boast the availability of credits to SME and their sustainability which of course will lead encourage more entrepreneurial engagements and all its positive outcomes. In the reminder of this paper, we shall review the literature in Section 2, methodology of research in Section 3, data analysis and result in Section 4 and conclusion in Section 5.

\section{Literature Review}

\subsection{Theoretical Review}

The concept Small and medium size enterprise (SME) has been widely examined in literature but however has no unique definition in that, what is considered as SME in one country vary in another. Within the context of Cameroon, reading from the National Assembly of Cameroon report, (2010), the Cameroon law stipulates that; SMEs are subdivided into three groups: Very Small Enterprises (micro enterprises), Small-sized Enterprises (SEs) and Medium-Sized Enterprises (MEs).

As vital as SMEs has be stipulated to be especially in the developing economies, their sustainability remain a major challenge. The approach to SME's sustainability in developing countries has been that of, "one solution fits all", with the same needs assumed and a cut across policy implemented from one country to the other Lack of access to finance and lack of managerial skills have often been cited as the main challenges (Ayuk et al., 2016). Financing SMEs consists the various means or source via which SMEs receives the funds necessary to run its daily operations, expand production, remain operation and sustainable. SMEs receive such funding through a variety of means, including revenue generated from the sale of services and products as well as from loans or the sale of stock (Douglass P. \& Sarah F., 2014). They may obtain it from friends and relatives as well.

According to Peñaloza (2015) Funding can be achieved internally or externally of the firm, internally the financial resources are generating via plough back profit, from Equity partners and cash flows. Once the enterprise needs for finance become greater than her capacity to finance, she must resort to external sources of finance if they have to achieve their objective and remain competitive. In this case the external finance can be raised via third parties, through commercial loans, bank acceptance, bonds, ordinary participation certificates, insurance bonds and stocks (Brealey et al., 2006). These sources allow companies to expand more rapidly than with internal and permit the creation of new business lines, infrastructure and innovation more rapidly.

The access to these external means of financing is determined by diverse factors in the financial market. Different theories have been put in place to explain the determinants of credit access in the financial market and include: The adverse selection theory of Stieglitz and Weiss (1981). According to this theory the lending interest rate cannot be equated to where demand and supply meet in the credit market simply because of the high asymmetry of in- 
formation between the lender (supplier of funds) and the borrower (demander of funds).

The borrower has full knowledge of his investment project, his intension as to pay back the loan or not, meanwhile the lender has no such clear information. Because lender find it difficult to distinguish between good and bad borrows and simply try to handle the case by increasing the credit interest rate to all, it can lead to adverse selection as only firms that are ready to pay such high risk who may in reality be the true defaulters of payment may be selected in the place of the true payers who because of excess price are driven away from accessing the credit. Another problem exposed by this theory is that of moral hazards which brings about limited access to credit.

Also as started by Mushinski (1999), credit market imperfections also result from costly monitoring and contract enforcement particularly in developing countries with a lack of proper legal system and marked poor development of property rights especially for SMEs as compared to large companies. This opinion brings in the aspect of a high cost of contract and transaction which turns to increase the cost of credit and hence limits its availability to only those firms capable to afford such high cost hence excluding a majority of SMEs.

To crown it all, diverse determinant of credit access has been highlighted in the literature. Among which are the firms size (the larger the firm the lesser it is credit constraint because they can easily provide the resources to repay the credit, Foxley (1999)); Age of the firms, the more experience the firm, the less constraints she is to credit since experience and high level consolidation stand as prove to repayment to the lender as compare to new or young firm, Characteristics of organizations, technological capacities, sectorial differences and location all constitute the determinants for credit access (Peñaloza, 2015). Also, Pandula (2011), examined the determinants of access to bank finance by SMEs in Sri Lanka by employing all three characteristics namely entrepreneur characteristics, firm characteristics and financial characteristics as significant aspects.

\subsection{Empirical Review}

The major theoretical concepts represented in the literature as determinants of credit access has been empirically tested by different research in different context and proven their validity. Peñaloza (2015) in a study examining the determinants of access to credit for SMEs at the level of firms in Latin America, using a world bank survey data on 110 formal and informal enterprises in the manufacturing and service sector, employing the discrete choice models, logit and probit model, revealed that the most important determinants that influences the probability of SMEs access to credit are internal such as size, and technological capacity. These factors increased the firm's competitiveness in the market place and hence ensured the creation of sustainable cash flows.

Pandula (2011), in an empirical investigation of small and medium enterprises' access to bank finance: the case of an emerging economy (sri lanka) using 
data obtained from the Investment Climate Survey carried out by the World Bank for Sri Lanka adopting the Chi square statistic method revealed that, education of the entrepreneur and having membership with business association are associated with access to bank finance.

The study effectuated by (Henri \& Edson, 2012) on impact the of entrepreneurial social capital on the credit access of SMEs in Cameroon, using a multinomial logit model showed that SMEs Cameroon used basically five indicators i.e. the ratio of family labor, government support, belonging to a business network, personal relation with the client bank and the level of human capital predominant in the enterprise resulted that among this elements, belonging to a business network, personal relations, human capital predominant positively affect access to bank credit. The study also shows that thanks to social capital, SMEs that have access to bank credit survive for a longer period than the others.

Also, a study undertaken by (Piabuo et al., 2015) on the effects of credit constraints on the Productivity of small and medium-sized enterprises in Cameroon, using data on Cameroon enterprise survey data collected by the World Bank in 2009, adopting an endogenous switching regression model revealed that interest rates, size of enterprise, size of loan, size of collateral, maturity of loans and legal status of enterprises are major sources of credit constraints faced by SMEs. Their results also indicated that Credit constrained firms have lower levels of productivity relative to unconstrained firms and that this effect is predominant for small enterprises than in medium enterprises. This present paper seeks to contribute to a better understanding of the determinants of access to credit by SMEs in Cameroon and its impact on their sustainability as a base for more targeted recommendation to policy makers.

\section{Methodology and Data}

From the specific objectives of this study which has to do with identifying the determinant of access to credit on the sustainability of small and medium sized enterprises and analysing the impact of access to credit on the sustainability of small and medium sized enterprises in Cameroon will be presented using the Probit model and the ordinary least squares method for the impact of access to credit on the sustainability of small and medium sized enterprises.

\subsection{Capturing the Access to Credit Function Using the Probit Model}

Our measure of credit demand is an indicator variable for entrepreneurs need for bank loans decreasing during a period mean while credit supply is measure by using information on whether an entrepreneur's application for a loan was rejected or the applicant received less than $75 \%$ of the amount demanded as loan. According to this study, several factors such as collateral, access to credit, duration of the credit, number of credits obtain, source of the credit, usage of the 
credit, gender and age have a significant impact on the demand for credit for the sustainable enterprise. This situation can be written in the form of a model.

Given the following model (Bin et al., 2020),

$$
\mathrm{AC}_{i}=\delta_{0}+\delta_{1} \mathrm{CS}_{i}+\sum_{i=2}^{n} \delta_{i} Z_{i}+\vartheta_{i}
$$

where $\mathrm{AC}=$ access to credit

$\mathrm{CS}=$ Collateral security

$Z_{i}=$ a vector of other variables

$\delta_{0}, \delta_{1}$, and $\delta_{i}$ are parameters to be estimated

$\vartheta_{i}=$ an error term. AC is a binary dependent variable case; it helps to view observable outcomes $\mathrm{AC}=1$ and $\mathrm{AC}=0$ as choice that depend on some unobservable variable $\mathrm{AC}^{*}$.

The latent regression framework is given as;

$$
\mathrm{AC}^{*}=\delta_{0}+\delta_{1} \mathrm{CS}_{i}+\sum_{i=2}^{n} \delta_{i} Z_{i}+\vartheta_{i}
$$

where;

$\mathrm{AC}=1$ if $\mathrm{AC}^{*}>0$, if the lender judges the applicant as credible.

$\mathrm{AC}=0$ if $A C^{*} \leq 0$, if the lender judges the applicant not credible.

If $\vartheta_{i}$ is assumed to be distributed normally then we can use the Probit framework to model the demand for credit which are the determinant of access to credit. Using the probability format, Equation (1) and (2) becomes

$$
\operatorname{Pr}(\mathrm{AC}=1 / X)=\nabla\left(\delta_{0}+\delta_{1} \mathrm{CS}_{i}+\sum_{i=2}^{n} \delta_{i} Z_{i}\right)
$$

where;

$$
\begin{aligned}
& \operatorname{Pr}=\text { the probability } \\
& X=\text { the vector of all independent variables } \\
& \nabla\left(\delta_{0}+\delta_{1} \mathrm{CS}_{i}+\sum_{i=2}^{n} \delta_{i} Z_{i}\right)=\text { the cumulative density function (coefficient) for the }
\end{aligned}
$$
standard normal distribution. After estimating the coefficients of the probit model, the marginal effect will also be reported.

\subsection{Estimating the Impact of Access to Credit on the Sustainability of SMEs Using the Ordinary Least Square Method (OLS)}

The ordinary list square method can be presented in a general manner as a relationship between a dependent variable $\mathrm{AC}$ and an explanatory variable CS and X in the form of a linear model (Bin et al., 2019; Ofeh et al., 2020). The equation can be presented as thus

$$
\mathrm{SE}_{i}=\beta_{0}+\beta_{1} \mathrm{AC}_{i}+\beta_{2} \mathrm{CS}_{i}+\sum_{i=3}^{n} \beta_{i} X_{i}+\varepsilon_{i}
$$

where;

$$
\begin{aligned}
& \mathrm{SE}=\text { Sustainable enterprises } \\
& \mathrm{AC}=\text { Access to credit } \\
& \mathrm{CS}=\text { Collateral security }
\end{aligned}
$$


$X=$ other characteristic variables of access to credit

$\beta_{0}, \beta_{1}, \beta_{2}$ and $\beta_{i}$ are regression coefficients or parameter

$\varepsilon_{i}$ is an error term. Based on the available data, the parameters $\beta_{0}, \beta_{1}, \beta_{2}, \beta_{i}$ are estimated with the used of the ordinary least squares method which provides the regression line that minimizes the sum of squares of the vertical distances from each point to the line. The vertical distances are the errors in the dependent variable.

\subsection{Presentation of Variables of the Study}

Table 1 represents the variables that were used for the estimation of the results.

\subsection{DATA}

We used the enterprise survey in Cameroon, which is a secondary dataset collected by World Bank 2016. The survey had as objectives to present the major factor that can boss the business environment of the economy of Cameroon and also presenting the factor that can contribute to the birth of enterprises and factors that can withhold the growth of small and medium sized enterprises in $\mathrm{Ca}$ meroon.

The business owners and top managers of 361 firms in Cameroon were interviewed in 2016 and this survey was carried out in the towns Douala, Yaoundé

Table 1. Nature and description of the variables used for the study.

\begin{tabular}{|c|c|c|}
\hline Variables & Nature & Description \\
\hline Access to credit (AC) & Dependent & 1 if entrepreneur have access to credit and 0 if not \\
\hline Collateral Security (CS) & Independent & $\begin{array}{l}1 \text { if the entrepreneur doesn't have a collateral security } \\
\text { and } 0 \text { if otherwise }\end{array}$ \\
\hline Sustainable enterprise (SE) & Dependent & It evaluates the productivity of SMEs \\
\hline & & $\begin{array}{l}\text { It is a dummy variable where }(1=\text { yes and } 0=\text { no }) \\
\text { - Bank }\end{array}$ \\
\hline Source of credit & Independent & $\begin{array}{l}\text { - Financial institution like MF } \\
\text { - Cooperatives } \\
\text { - NGO'S }\end{array}$ \\
\hline Political instability & Independent & 1 if there is Political instability and 0 if not \\
\hline Duration of credit & Independent & $\begin{array}{l}1 \text { if the length of time to reimburse the loan is quiet } \\
\text { long and } 0 \text { if otherwise }\end{array}$ \\
\hline Size of credit & Independent & $\begin{array}{l}\text { Dummy variable where }(1=\text { yes and } 0=\text { no }) \\
\text { - Large } \\
\text { - Medium } \\
\text { - Small }\end{array}$ \\
\hline Number of credits obtained & Independent & $\begin{array}{l}1 \text { if the entrepreneur has applied for a loan before } \\
\text { and } 0 \text { if otherwise }\end{array}$ \\
\hline Usage of the credit & Independent & 1 if for creation of an enterprise and 0 if otherwise \\
\hline Savings & Independent & 1 if the entrepreneur has savings and 0 if otherwise \\
\hline
\end{tabular}

Source: constructed by author using enterprise survey 2016 dataset. 
and Bafoussam. Carried out in two stages, where in the first stage a telephone screening was made to schedule an interview with the managers and confirm their eligibility and in the second stage, a face-to-face interview with a top manager of the firm was conducted.

\section{Empirical Results}

\subsection{Capturing the Determinants of Access to Credit for the Sustainability of SMEs}

From the results in Table 2, collateral security decreases the probability of having access to credit by $6.06 \%$. This is explained by the fact that Collateral security is often demanded by a financial institution as one of the alternative measures to mitigate the risk of default by borrowers (Piabuo et al., 2015).

The probability of an enterprise having access to credit decreases with an increase in interest rate. This is because it is the price of borrowing money and also used by banks as a measure to cover other costs of obtaining information, especially in an economy like that of Cameroon with high information asymmetry (Stieglitz \& Weiss, 1981).

Furthermore, manager's experience significantly increases the chances of having access to credit by $1.16 \%$ at $5 \%$ level. This is because when a manager has acquired a lot of experience it increases his/her competences and skills of managing a loan and banks will be sure that their money will come back and will reduce the chances of default risks.

Corruption reduces the probability of having access to credit by $13.3 \%$ which is statistical insignificant. This result is explained by the fact that, banks in Cameroon gives loans either by cultural, religious or family ties and bank managers even go a long way to give loans to those that can give an extra amount above the interest set by the banks and banking regulations.

Another influential determinant of access to credit is political instability which significantly decreases the chances of having access to credit by $27.5 \%$ at $1 \%$ level. which is explained by the fact that since 2014 Cameroon has suffered from Boko Haram in the northern region and at the end of 2016 till date with Anglophone crisis which has made banks to be skeptical in giving out loans and thus, demanding heavy collateral security which reduces the chances of having access to credit.

As far as the legal status of an enterprise is concern, the sole proprietor business increases the probability of having access to credit by $29.2 \%$ and is statistically significant at 5\%, compare to partnership and Joint Stock Company which reduces the chances of having access to credit by $49.5 \%$ and $59.6 \%$ which is statistically significant at 5\%,10\% respectively. For sole proprietor business this explain by the fact that, sole proprietors have interacted very well with their financial institutions so this goes a long way to reduce the problem of asymmetry information through the process of moral hazard and adverse selection and usually increase the demand for short-term loans (Wenda, Engwali, \& Ofeh, 2020). 
Table 2. Determinants of access to credit for the sustainability of SMEs.

\begin{tabular}{|c|c|c|c|}
\hline & (1) & (2) & (3) \\
\hline VARIABLES & Marginal effects & Probit coefficients & OLS coefficients \\
\hline \multirow[t]{2}{*}{ COLLATERAL SECURITY } & -0.0606 & -0.353 & -0.0259 \\
\hline & $(0.131)$ & $(0.768)$ & $(0.137)$ \\
\hline \multirow[t]{2}{*}{ INTEREST RATE } & -0.199 & -1.160 & -0.136 \\
\hline & $(0.122)$ & $(0.763)$ & $(0.133)$ \\
\hline \multirow[t]{2}{*}{ MANAGER'S EXPERIENCE } & $0.0116^{\star *}$ & $0.0676^{\star *}$ & $0.00966^{\star}$ \\
\hline & $(0.00487)$ & $(0.0319)$ & $(0.00567)$ \\
\hline \multirow[t]{2}{*}{ CORRUPTION } & -0.133 & -0.777 & -0.0811 \\
\hline & $(0.118)$ & $(0.720)$ & $(0.170)$ \\
\hline \multirow[t]{2}{*}{ POLITICAL INSTABILITY } & $-0.275^{\star * *}$ & $-1.604^{\star *}$ & $-0.240^{\star}$ \\
\hline & $(0.105)$ & $(0.723)$ & $(0.122)$ \\
\hline \multirow[t]{2}{*}{ TAX RATES } & $0.105^{\star * *}$ & $0.613^{* *}$ & 0.0818 \\
\hline & $(0.0394)$ & $(0.279)$ & $(0.0498)$ \\
\hline \multirow[t]{2}{*}{ PARTNERSHIP } & $-0.475^{\star *}$ & $-2.768^{* *}$ & -0.337 \\
\hline & $(0.207)$ & $(1.401)$ & $(0.349)$ \\
\hline \multirow[t]{2}{*}{ JOINT STOCK } & $-0.596^{\star * *}$ & $-3.475^{\star *}$ & $-0.457^{\star}$ \\
\hline & $(0.183)$ & $(1.375)$ & $(0.246)$ \\
\hline \multirow[t]{2}{*}{ SIZE OF LOAN } & $-0.0722^{\star * *}$ & $-0.421^{\star *}$ & $-0.0603^{\star *}$ \\
\hline & $(0.0235)$ & $(0.170)$ & $(0.0226)$ \\
\hline \multirow[t]{2}{*}{ GENDER (1 IF MALE AND 0 IF NOT) } & $-0.263^{\star *}$ & $-1.535^{\star}$ & -0.305 \\
\hline & $(0.120)$ & $(0.802)$ & $(0.203)$ \\
\hline \multirow[t]{2}{*}{ REGISTRATION } & 0.168 & 0.978 & 0.0424 \\
\hline & $(0.199)$ & $(1.175)$ & $(0.163) 4$ \\
\hline \multirow[t]{2}{*}{ LOAN BEFORE } & -0.0145 & -0.0845 & -0.0200 \\
\hline & $(0.0941)$ & $(0.550)$ & $(0.116)$ \\
\hline \multirow[t]{2}{*}{ INADIQUATE EDUCATED LABOUR } & $0.150^{* * *}$ & $0.874^{\star * *}$ & $0.122^{* *}$ \\
\hline & $(0.0452)$ & $(0.338)$ & $(0.0528)$ \\
\hline \multirow[t]{2}{*}{ SOLEPROPRITOR } & $0.292^{* *}$ & $1.703^{*}$ & 0.249 \\
\hline & $(0.146)$ & $(0.944)$ & $(0.250)$ \\
\hline \multirow[t]{2}{*}{ CONSTANT } & & $10.75^{\star * *}$ & $2.120^{* * *}$ \\
\hline & & $(4.040)$ & $(0.594)$ \\
\hline OBSERVATIONS & 361 & 361 & 361 \\
\hline R-squared & & & 0.350 \\
\hline
\end{tabular}

Standard errors in parentheses. ${ }^{* *} p<0.01,{ }^{* *} p<0.05,{ }^{*} p<0.1$. Source: constructed by author using enterprise survey 2016 dataset.

More so, gender i.e. male reduces the chances of having access to credit and is statistically significant at $5 \%$ and this is explained by the fact that male lenders 
don't have a convincing way as compare to their female counterparts. Also, taxes rate and the education level of the work force increases the probability of having access to credit by $10.5 \%$ and $15 \%$ respectively and are statistically significant at $1 \%$ level.

Again, the amount of the loan significantly reduces the probability of having access to credit at $5 \%$ level. This is because the higher the amount of loan the higher the amount paid as interest and the higher the collateral security which increases the constraints to credit.

From the results of the ordinary least square, it shows that the major determinants of access to credit have a negative impact on access to credit. Like manager's experience which has a positive impact on access to credit showing a unit increase in manager's experience increases access to credit by $0.96 \%$ and is statistically significant at $10 \%$, political instability significantly reduces access to credit by $24 \%$ at $10 \%$ level, tax rates, gender ( 1 if male and 0 if not) inadequate educated labour, interest rate, collateral security and corruption.

Finally, from the results of the probit model it shows that, the major determinants of access to credit are manager's experience, political instability, tax rates, gender ( 1 if male and 0 if not) inadequate educated labour, interest rate, collateral security and corruption.

\subsection{Estimation of the Impact of Access to Credit on Sustainability of SMEs}

From the results of the ordinary least square in Table 3, it shows that; Access to credit has a positive impact on the sustainability of SMEs in Cameroon, showing that a unit increase in access to credit will lead to a $59 \%$ increase on the sustainability of SMEs in Cameroon and is statistical significant at $10 \%$. This result can further be explained by the fact that the more entrepreneurs don't have credit constraint it leads to an increase in the productivity of the enterprise and which in return increases the amount of jobs created and hence reduces the level of unemployment in the economy (ILC, 2007).

Political instability significantly has a negative impact on the sustainability of SMEs in Cameroon, showing that a unit increase in political instability will decrease sustainability by $73.3 \%$ at $1 \%$ level. This result is practically true for the case of Cameroon because small and medium sized enterprises has close down due to the political instability in the country and especially in the North West, South west, North, Far North region and the East region and this has greatly affected the entire economy because these regions serves as a markets for the other regions like Douala, Yaoundé and west region and access to credit has become very difficult.

For an enterprise that has taken a loan before will decrease her chances of having a loan and hence reduces the sustainability of SMEs. Where by a unit increase for a firm that have taken a loan before, will lead to a fall on the sustainability of SMEs. 
Table 3. Estimation of the Impact of access to credit on sustainability of SMEs.

\begin{tabular}{|c|c|}
\hline & (1) \\
\hline VARIABLES & OLS coefficients \\
\hline \multirow[t]{2}{*}{ ACCESS TO CREDIT } & $0.590^{*}$ \\
\hline & $(0.313)$ \\
\hline \multirow[t]{2}{*}{ COLLATERAL } & -0.916 \\
\hline & $(0.828)$ \\
\hline \multirow[t]{2}{*}{ CORRUPTION } & 0.117 \\
\hline & $(0.314)$ \\
\hline \multirow[t]{2}{*}{ POLITICAL INSTABILITY } & $-0.733^{\star \star \star}$ \\
\hline & $(0.237)$ \\
\hline \multirow[t]{2}{*}{ TAX RATES } & 0.127 \\
\hline & $(0.0920)$ \\
\hline \multirow[t]{2}{*}{ EXPERIENCE } & 0.00828 \\
\hline & $(0.0417)$ \\
\hline \multirow[t]{2}{*}{ EXPERIENCE SQUARE } & 0.000468 \\
\hline & $(0.000958)$ \\
\hline \multirow[t]{2}{*}{ AMOUNT OF LOAN } & 0.166 \\
\hline & $(0.153)$ \\
\hline \multirow[t]{2}{*}{ LOAN BEFORE } & $-0.829^{* *}$ \\
\hline & $(0.362)$ \\
\hline \multirow[t]{2}{*}{ AGE } & $0.0716^{* *}$ \\
\hline & $(0.0278)$ \\
\hline \multirow[t]{2}{*}{ SAVING ACCOUNT } & $0.784^{* * *}$ \\
\hline & $(0.250)$ \\
\hline \multirow[t]{2}{*}{ DURATION OF LOAN } & $0.259^{* *}$ \\
\hline & $(0.118)$ \\
\hline \multirow[t]{2}{*}{ AGE SQUARE } & $-0.001000^{\star * \star}$ \\
\hline & $(0.000301)$ \\
\hline \multirow[t]{2}{*}{ CONSTANT } & $14.44^{\star * *}$ \\
\hline & $(2.857)$ \\
\hline OBSERVATIONS & 361 \\
\hline R-SQUARED & 0.289 \\
\hline
\end{tabular}

${ }^{* * *} p<0.01,{ }^{* *} p<0.05,{ }^{*} p<0.1$. Source: constructed by author using enterprise survey 2016 dataset.

Having a saving account in a bank, increases the sustainability of SMEs. A unit increase in a saving account increases the sustainability of SMEs by $78.4 \%$ which is statistically significant at $1 \%$. This will increase sustainability because having an account will encourage the bank to give a loan to her customer and 
also depending on the amount saved in the account.

Furthermore, the duration of the loan will have a positive impact on the sustainability of SMEs. Showing that a unit increase in the duration of the loan will lead to $25.9 \%$ increase on the sustainability of SMEs. Since the duration of the loan will permit the firm to have enough time to invest and recover the loan.

Finally, from the age of 1 to 35.5 years the sustainability of SMEs will increase and above that age the sustainability of SMEs will become constant and later fall showing that the age of the enterprise is a maximum turning point. This result shows that the life cycle of a firm increases at a particular age, becomes constant and later on falls with respect to the sustainability of the enterprise. This indicates that the sustainability of the firm follows the law of diminishing returns to scale.

\section{Concluding Remarks}

The probit regression showed that the lack of collateral security reduces the probability of SMEs having access to credit by $6.06 \%$. Having collateral security is a necessary condition to have access to credit from a microfinance institution. Size of loan, political instability, corruption, the legal status of an enterprise, manager's experience and interest rate are the principal determinants which decrease the probability of enterprises having access to credit by $27.5 \%, 7.2 \%$, $13.3 \%, 1.16 \%$ and $19.9 \%$ respectively and these are the major determinants of access to credit. From the ordinary least square estimates of access to credit on the sustainability of SMEs in Cameroon, it shows that access to credit has a positive impact on the sustainability of SMEs in Cameroon where, a unit increase in access to credit will lead to a 59\% increase on the sustainability of SMEs.

These findings have implication to enhance SMEs access to credit where the government can formulate an entrepreneurship policy by increasing the number banks for small and medium size enterprises and offer microcredit facilities that can grant loans at low interest rates and help to enhance the environmental Optimizing laws, entrepreneurship education and skills, facilitating technology exchange and innovation, improving access to finance, promoting awareness and networking which go a long way to reduce the problem of asymmetry information. Also, the government can also take an investigative strategy by reducing the rate of corruption, political instability and revamping the banking prudential regulations.

\section{Limitation of Research}

This work has limitation that the data used are for 2016 and it was difficult to have recent data. So further studies can look for more recent data.

\section{Contribution/Originality}

This article contributes to knowledge as a case study in Cameroon. It explains the determinants of access to credit and some challenges in the subject matter 
and gives the policy-maker a chance to appreciate principles of effective entrepreneurship policy for the sustainability of SMEs.

\section{Conflicts of Interest}

The authors declare no conflicts of interest regarding the publication of this paper.

\section{References}

Ayuk, J. A., Bystryakov, A. Y., \& Karpenko, O. A. (2016). Financing Sustainable Development of Small and Medium Enterprises in Cameroon. International Journal of Environmental \& Science Education, 11, 8062-8076.

Bin, J. M., Emmanuel, S. M., \& Theodore, B. N. (2019). The Structure-Conduct-Performance Paradigm: An Empirical Analysis of Cameroon Firms. Journal of Business Economics and Management, 7, 316-323.

Bin, J. M., Moses, O. A., \& Sergeo, B. C. (2020). Impact of the Corona Pandemic on Household Welfare in Cameroon. Journal of Economics and Management Sciences, 3, 25. https://doi.org/10.30560/jems.v3n3p25

Brealey, R. A., Myers, S. C., Allen, F., Soria, L. N., \& Izquierdo, M. A. (2006). Principios Finanzas Corporativas. Madrid: Mcgraw-Hill.

Douglass, P., \& Sarah, F. (2014). Rethinking SME Finance Policy-Harnessing Technology and Innovation. The World Bank SME Finance Forum.

Foxley, J. (1999). Limitantes al financiamiento de las empresas de menor tamano. Santiogo de chile: Proyecto conjunto ministerio de economia CORFO banco del estadoCEPAL.

Henri, N. T., \& Edson, N. S. (2012). Accès au crédit bancaire et survie des PME camerounaises: Le rôle du capital social (Bank Credit Access and Cameroonians SMEs Survival: Does Social Capital Matter?). Revue Africaine des Sciences Economiques et de Gestion, 19, 111-136.

ILC (2007). Year Book of the International Labour Commission. Geneva: United Nation.

Mullei, A. (2003). Growth and Transformation of Small Manufacturing Firms in Africa: Insights from Ghana, Kenya and Zimbabwe. Nairobi: African Center for Economic Growth.

Mushinski, D. (1999). An Analysis of Offer Functions of Banks and Credit Unions in Guatemala. Journal of Development Studies, 26, 88-112.

https://doi.org/10.1080/00220389908422622

Mwabili, J. S. (2014). An Analysis of the Determinants of Access to Credit by Small and Medium Enterprises in the Informal Sector in Ongata Rongai. Nairobi: University of Nairobi.

National Institute of Statistics (NIS) (2009). Recensement général des entreprises 2009, principaux. Yaounde: NIS.

Nguyen, M., Arovas, G., Broach, D., Cateriano, H., \& Righi, P. (2004). The Development Impact of Small and Medium Enterprises: Lessons Learnt from SEAF Investments (p. 33). Washington DC: Small Enterprise Assistance Funds.

OECD (2004). Business Incubation: International Case Studies. Paris: OECD Publications Service.

Ofeh, M. A., Bin, J. M., \& Che, S. B. (2020). An Empirical Analysis of the Impact of Decentralization on Poverty in Cameroon. Journal of Social Economics Research, 7, 91- 
106. https://doi.org/10.18488/journal.35.2020.72.91.106

Ofoegbu, E. O., Akanbi, P. A., \& Joseph, A. T. (2013). Effect of Contextual Factors on the Performance of SMEs in Nigeria: A Case Study of Ilorin Metropolis. Advance in Management and Applied Economics, 3, 95-114.

Olowe, F. T., Moradeyo, O. A., \& Babalola, O. A. (2013). Empirical Study of the Impact of Microfinance Bank on Small and Medium Growth in Nigeria. International Journal of Academic Research in Economics and Management Sciences, 2, 116-124. https://doi.org/10.6007/IJAREMS/v2-i6/465

Pandula, G. (2011). An Empirical Investigation of Small and Meduim Size Enterprises' Access to Bank Finance: The Case of Emerging Economy. Proceedings of ASBBS, Las Vegas, 24-27 February 2011, 255-273.

Peñaloza, H. A. (2015). Determinants of Access to Credit for SMEs: Evidence at the Level of Firms in Latin America. Apuntes Cenes, 34, 247-276. https://doi.org/10.19053/22565779.3781

Piabuo, S. M., Baye, F. M., \& Tieguhong, J. C. (2015). Effects of Credit Constraints on the Productivity of Small and Medium-Sized Enterprises in Cameroon. Journal of Economics and International Finance, 7, 204-212.

https://mpra.ub.uni-muenchen.de/67135

Stieglitz, J. E., \& Weiss, A. (1981). Credit Rationing in Markets with Imperfection Information. American Economic Review, 71, 393-410.

Wenda, B. D., Engwali, D. F., \& Ofeh, M. A. (2020). Assessing the Contribution of Micro Credit Financing to Maize Production in Mezam Division, North West Region of Cameroon. International Journal of Agricultural Economics, 5, 9-17. https://doi.org/10.11648/j.ijae.20200501.12

World Bank/IFC (2008). Enterprise Survey World Bank/ICF (2008), Doing Business: Measuring Business Regulations. Washington DC: World Bank Group. 